\title{
Fortification of dextran and mannitol in sweet pumpkin by fermentation with Leuconostoc mesenteroides SM
}

\author{
Jong-Soon Lim ${ }^{1}$, Young-Cheol Son ${ }^{2}$, Dong-Cheol Park ${ }^{3}$, Sam-Pin Lee ${ }^{1,2 *}$ \\ ${ }^{1}$ The Center for Traditional Microorganism Resource (TMR), Keimyung Univerity, Daegu 42601, Korea \\ ${ }^{2}$ Department of Food Science and Technology, Keimyung University, Daegu 42601, Korea \\ ${ }^{3}$ Department of Hotel Cuisine and Food Service Management, Gimcheon College, Gimcheon 39528, Korea
}

\section{Leuconostoc mesenteroides SM 젖산균 발효를 통한 dextran과 mannitol 강화 단호박 발효물 생산}

\author{
임종순 ${ }^{1} \cdot$ 송영철 $^{2} \cdot$ 박동철 $^{3} \cdot$ 이삼빈 $^{1,2 *}$ \\ ${ }^{1}$ 계명대학교 TMR센터, ${ }^{2}$ 계명대학교 식품가공학전공, ${ }^{3}$ 김천대학교 호텔조리외식경영학과
}

\begin{abstract}
Sweet pumpkin paste (SPP) was fermented by Leuconostoc mesenteroides SM at $25^{\circ} \mathrm{C}$ for 3 days for enhancing its physicochemical properties. SPPs with $5 \%, 10 \%$, and $15 \%$ solid contents (SC) were fortified with $20 \%$ sucrose and $0.5 \%$ yeast extract. The unfermented SPP with $15 \%$ SC indicated $\mathrm{L}$, a, and b color values of 25.02, 4.66, and 13.35, respectively, and a consistency index of $48.6 \mathrm{~Pa} \cdot \mathrm{s}^{\mathrm{n}}$. During the 3 days of fermentation, both the a and b color values decreased slightly, whereas the consistency index increased to $188.8 \mathrm{~Pa} \cdot \mathrm{sn}$, giving the fermented product a pudding-like consistency. This fermented SPP (15\% SC) showed the highest acid production and viable cell counts among samples, indicating $\mathrm{pH} 3.85,1.30 \%$ acidity and $9.2 \times 10^{8} \mathrm{CFU} / \mathrm{mL}$ respectively. The added sucrose was completely utilized after 1 day of fermentation. After 3 days, the insoluble and soluble dextran contents were $8.9 \%$ and $4.5 \%$, respectively. Furthermore, the contents of mannitol and fructose were $3.11 \%$ and $1.76 \%$, respectively. Regarding the sensory evaluation, this fermented sample also indicated the highest color, taste and texture scores, and was the overall preferred sample. In conclusion, the fermented SPP with $15 \%$ SC was carotinoid-rich a wholesome pumpkin-based product that is rich in probiotics and lactic bacteria-produced mannitol and dextran, which gave the product an acceptable viscous pudding-like consistency and good organoleptic properties.
\end{abstract}

Key words : sweet pumpkin, Leuconostoc mesenteroides, dextran, mannitol, pudding

\section{서 론}

단호박(Cucurbita maxima)은 박과에 속하는 1년생 덩굴 성 초본으로 남아메리카 페루가 원산지인 서양계 호박으로 기호성 작물이며, vitamin $\mathrm{A}, \mathrm{B}_{1}, \mathrm{~B}_{2}, \mathrm{C}$ 의 함량이 높으며 그 외에도 칼슘, 나트륨, 인 등의 무기질 함량이 풍부하여

*Corresponding author. E-mail : splee@ $@$ kmu.ac.kr

Phone : 82-53-580-5554, Fax : 82-53-580-6447

Received 16 March 2016; Revised 28 April 2016; Accepted 7 June 2016.

Copyright (c) The Korean Society of Food Preservation. All rights reserved.
영양적으로 우수한 식품이다(1). 대표적 phytochemical인 $\beta$-carotene의 함량이 높고, 섬유질이 풍부하여 항암효과 부종의 치료 및 이뇨효과가 있다고 보고되었다 $(2,3)$. 또한 늙은 호박(Cucurbita moschata)보다 전자 공여에 의한 라디 칼소거능, $\mathrm{SOD}$ 유사 활성과 아질산염 소거작용에 대한 활 성이 우수한 것으로 나타났다(4). 최근 건강소재로서 컬러 푸드가 알려지면서 식욕을 자극하는 노란 색소를 함유한 단호박은 대표적인 옐로우 푸드로서 저칼로리 식품이면서 포만감을 주어 다이어트에 도움이 되는 식품소재로 알려져 있다(5).

건강소재인 다양한 식물소재들을 당절임하여 숙성 발효 시키는 연구는 활발하게 진행되어 보고(6) 되었으며, 호박 
등의 야채를 젖산균에 의한 발효를 통해서 발효음료 제조에 관한 연구가 보고되었다 $(7,8)$. 하지만 단호박을 원료로 하 여 기호성과 기능성을 함께 증진시키는 수단으로 발효를 수행한 연구는 매우 미비한 실정이다.

푸딩(pudding)은 달걀과 설탕, 우유 등을 섞어 익혀낸 겔상 식품으로서 디저트로 소비되며, 단백질, 탄수화물, 지 질 등의 많은 영양물질을 포함하며 소화 흡수가 빠르게 된다(9). 특히 푸딩 및 젤리와 같은 겔상 식품은 조직감이 매우 중요하여 입안에서 느끼는 감촉이 식품의 맛과 기호성 에 큰 영향을 준다. 국내외에서는 젤화 제품으로 젤라틴, 한천, 펙틴, 카라기난, 곤약, 구아검 등 다양한 겔화제 첨가 에 따른 물성의 차이가 연구되고 있다(10-12). 우유의 젖산 발효에 의한 커드 형성도 일종의 겔상의 조직감을 갖는 발효제품으로 건강지향적인 추세에 따라 다양한 형태의 우유 발효식품의 소비가 증가되고 있는 실정이다. 최근 식 품의 원료에 기인한 알레르기에 민감한 소비자들이 나타나 면서 동물성 원료들의 섭취에 대한 알레르기 현상을 저감화 하기 위한 방안으로 발효식품에 관한 연구가 진행되었다 (13). 따라서 유당 불내증(lactose intolerance)을 유발하는 우유 같은 동물성 원료 이외에 채소류를 이용하여 기호성과 기능성이 강화된 건강 지향적 푸딩제품의 개발이 요구되 며, 이를 위해서 유용 미생물을 이용한 발효를 통해서 맛, 물성 및 기능성이 개선된 제품 개발이 필요하다.

대표적인 probiotic인 젖산균은 발효성 당으로부터 젖산 을 주로 생산하며, 장내에서 유해균의 생육을 억제시키며 정장작용 및 면역증진에 기여하는 것으로 보고되었다(14). 김치 발효에 관여하는 젖산균 Lactobacillus plantarum은 정상발효 균으로 발효성으로부터 젓산을 주로 생산하는 반면에 이상발효 젖산균 Leuconsotoc sp.는 김치의 숙성에 관여하는 대표적인 젖산균이며 젖산 이외에 당알코올, 탄 산가스를 생산한다(15). 특히 김치숙성에 관여하는 Leuconostoc 균주는 세포외 효소로서 dextransucrase를 분비 하면서 포도당의 중합체로서 고분자 dextran을 생합성하며 (16), 점착성, 흡습성 및 열안정성의 물리화학적 성질을 가 지면서 식품의 물성조절에 중요한 역할을 하는 것으로 보고 되었다 $(17,18)$. 또한 Leuconostoc 젓산균은 설탕으로부터 당 알코올인 만니톨, 과당 등을 생산하면서 발효제품에 단 맛과 상큼한 맛을 부여하는 역할을 한다(19). 젓산균에 의해 서 생산되는 당알코올은 화학적으로 고온 고압조건에서 수소첨가에 의한 생산방법에 비해서 장점이 있어 미생물에 의한 만니톨 생산에 관한 많은 연구들이 보고되었다(20). 최근 제과 제빵공정에서 설탕을 대신하여 다양한 당 알코 올을 사용함으로서 건강지향적인 케익 및 쿠키 제품을 제조 하는 연구가 보고되었다(21).

본 연구에서는 웰빙식품 소재인 단호박 분말과 식물성 유래 젖산균을 이용하여 기능성 물질을 강화시키는 발효 최적화를 수행하였으며, 미생물 유래 mannitol과 점질물 dextran 생산을 통해서 맛과 물성이 개량되며 probiotic를 함유한 단호박 젖산 발효물(푸딩) 소재를 개발하는 연구를 수행하였다.

\section{재료 및 방법}

재 료

본 연구에 사용된 단호박 분말은 이든타운 F\&B(Incheon, Korea)에서 구매하여 사용하였다. 설탕과 yeast extract(YE) 는 각각 대한제당(Incheon, Korea), (주조흥(Ansan, Korea)에 서 구입하였으며 분석에 사용한 시약은 모두 특급 시약을 사용하였다.

\section{Starter 배양액 제조}

당근에서 분리된 젓산균 Leuconostoc mesenteroides SM 은 설탕 함유 액체배지(sucrose $2 \%, \mathrm{YE} 0.5 \%$, tryptone $0.25 \%, \mathrm{~K}_{2} \mathrm{HPO}_{4} 0.25 \%$ )를 이용하여 MRS agar plate에서 각 각 배양시킨 균주를 1회 접종한 후 항온배양기(SI-990R, Jeio tech Co., Ltd., Daejeon, Korea)에서 $25^{\circ} \mathrm{C}$ 에서 24시간 동안 정치 배양한 후 스타터로 사용하였다(22).

\section{단호박 분말의 젖산발효}

단호박 분말을 $5 \%, 10 \%, 15 \%$ 함유하는 각각의 조건에서 설탕 $20 \%, \mathrm{YE} 0.5 \%$ 를 혼합한 용액을 $121^{\circ} \mathrm{C}$ 에서 15 분간 멸균하여 액체 배양한 Leu. mesenteroides SM을 $1 \%$ 을 접종 하여 $25^{\circ} \mathrm{C}$ 에서 3 일간 발효하였다.

\section{$\mathrm{pH}$, 산도 및 생균수 측정}

$\mathrm{pH}$ 는 $\mathrm{pH}$ meter(model 420+, Thermo Orion, Beverly, MA, $\mathrm{USA}$ )로 측정하였다. 적정 산도는 시료를 $1 \mathrm{~mL}$ 에 증류수 $9 \mathrm{~mL}$ 을 첨가하여 $0.1 \mathrm{~N} \mathrm{NaOH}$ 를 이용해 $\mathrm{pH} 8.3$ 까지 적정한 소비량을 젓산 함량 $(\%, \mathrm{v} / \mathrm{v})$ 으로 환산하였다. 생균수는 발 효물 $1 \mathrm{~g}$ 에 멸균수 $9 \mathrm{~mL}$ 을 첨가하여 10 배 희석법을 이용하 여 $10^{4}, 10^{5}, 10^{6}$ 배로 희석된 것을 MRS agar plate에 $20 \mu \mathrm{L}$ 도말한 후, $25^{\circ} \mathrm{C}$ 항온배양기에서 48 시간 배양한 후 생균수 를 $\mathrm{CFU} / \mathrm{g}$ 으로 나타내었다.

\section{점조도 측정}

단호박 젖산 발효물의 점조도는 Rheometer System (HAKKE RheoStress 1, Karlsruhe, Germany)에 cone plate device(Plate PP35Ti, $3.5 \mathrm{~cm}$ diameter)를 장착하여 측정하였 다. 발효물 $1 \mathrm{~g}$ 을 plate에 올려 구간 당 10 초 동안의 평균값이 측정되어 얻은 값을 shear rate $(1 / \mathrm{s})$ 와 shear stress $(\mathrm{Pa})$ 로 나타 내어 점조도를 측정하였다. 측정온도는 $20^{\circ} \mathrm{C}$ 에서 전단속도 (Í)는 1-100 s $\mathrm{s}^{-1}$ 의 범위로 유동특성을 알아보고, 점조도 지수 는 Power's law model로 평가하였다. 
Power's law model : $\sigma=\mathrm{K} \cdot \hat{\Gamma}^{\mathrm{n}}$

б는 전단응력(shear stress, $\mathrm{Pa}$ ), $\mathrm{K}$ 는 점조도 지수 (consistency index, $\mathrm{Pa} \cdot \mathrm{s}^{\mathrm{n}}$ ), 드는 전단속도(shear rate, $\mathrm{s}^{-1}$ ), $\mathrm{n}$ 은 유동성 지수(flow behavior index, n)이다.

\section{색도 측정}

단호박 젖산 발효물의 냉장 저장중에 색도 변화를 측정 하였다. 시료를 색도 측정용 검정색 알루미늄 용기(Konica Minolta CR-A50, inside diameter $24 \mathrm{~mm}$ )에 담아 Chroma meter(CR-400, Konica Minolta, Osaka, Japan)를 이용하여 $\mathrm{L}$ (lightness), $\mathrm{a}$ (redness), $\mathrm{b}$ (yellowness) 값을 측정하였다. 표 준 백색판은 $\mathrm{L}$ 값 $97.41, \mathrm{a}$ 값 $5.12, \mathrm{~b}$ 값 -3.86 이었다.

\section{Sucrose 소진율, fructose 및 mannitol 함량 측정}

Sucrose 소진율과 mannitol 함량 분석은 HPLC(Knauer Co., Berlin, Germany)를 이용하여 측정하였다. 발효액을 증류수에 10 배 희석 및 혼합한 후 $22,250 \times \mathrm{g}$ 에서 10 분간 원심 분리하여 상등액을 회수하였다. 회수한 용액을 0.45 $\mu \mathrm{m}$ syringe filter로 여과한 다음, 여액 $20 \mu \mathrm{L}$ 를 $\mathrm{HPLC}$ 분석용 시료로 사용하였다. HPLC 분석 시 검출기는 RI를 이용하였 으며, 당분석 전용 Asahipak NH2P 50 column(Shodex, Tokyo, Japan)을 이용하여 이동상을 $75 \%$ acetonitrile로 유속 은 $1.0 \mathrm{~mL} / \mathrm{min}$ 의 속도로 흘려주었다(23). mannitol과 fructose의 함량은 SUGAR SC1011 column (Shodex, Tokyo, Japan)을 이용하여 이동상을 $\mathrm{H}_{2} \mathrm{O}$ 로 유속은 $0.6 \mathrm{~mL} / \mathrm{min}$ 의 속도로 흘려주었다.

\section{Dextran 함량 측정}

L. mesenteroides SM에 의해 젖산발효 후에 생성된 수용 성 dextran 측정을 위해서 발효물을 증류수로 5 배 희석하여 $22,250 \times \mathrm{g}$ 에서 15 분간 원심분리 하였다. dextran 고분자를 회수하기 위해 수용성 dextran이 포함된 상등액에 $-20^{\circ} \mathrm{C}$ 에 서 보관된 에탄올을 2 배를 첨가하여 dextran을 응집시켰다. 침전된 dextran 중합체를 원심분리기로 $22,250 \times \mathrm{g}$ 에서 15 분 간 원심분리하고 증류수로 dextran을 용해하였다. 에탄올 침전 과정을 3회 반복하여 dextran을 얻었다. 불용성 dextran 물질을 상온에서 보관된 $\mathrm{KOH} 10 \%(\mathrm{w} / \mathrm{v})$ 용액에 용해시킨 후 균체로부터 dextran을 분리하기 위하여 $22,250 \times \mathrm{g}$ 에서 15 분 동안 원심 분리하여 상등액을 회수하였다(24). 알칼리 용액에서 용해된 불용성 dextran을 응집시키기 위해 $-20^{\circ} \mathrm{C}$ 에서 보관된 2 배의 에탄올 용액을 첨가하여 dextran을 응집 시켜 회수하고 $100 \%$ 에탄올로 세척하였다.

\section{관능검사}

단호박 젖산 발효물의 기호도를 조사하기 위하여 훈련한 패널 10 명을 선정하여 각 구별로 색, 단맛, 신맛, 쓴맛, 조직 감, 전반적 기호도로 항목을 나누어 5 점 척도법 $(1=$ 매우 싫
다, 5=매우 좋다)으로 실시하였다

\section{통계처리}

연구 결과는 평균값과 표준편차로 나타내었으며, 통계처 리는 SPSS(statistical package for social science, 20.0, SPSS Inc., Chicago, IL, USA)를 이용하여 one way ANOVA 분석 을 실시한 후 Duncan의 다중비교법으로 분석하였다. $\mathrm{p}<0.05$ 이상일 때만 통계계적 유의성이 있는 것으로 나타내 었다(25).

\section{결과 및 고찰}

$\mathrm{pH}$, 산도 및 생균수 측정

단호박 분말의 젖산발효를 위해서 단호박 분말 첨가량에 따라 젓산균 Leu. mesenteroides SM으로 발효시킨 단호박 페이스트의 $\mathrm{pH}$, 산도 변화를 Fig. 1에 나타내었다. 발효물의 $\mathrm{pH}$ 는 발효 초기 모든 조건에서 $\mathrm{pH} 5.83$ 정도로 약산성으로 단호박 분말 첨가량에 따른 차이는 없는 것으로 나타났다. 젖산 발효 1 일 후에 $\mathrm{pH}$ 는 4.0 수준으로 크게 감소한 후 발효 3일 동안 $\mathrm{pH}$ 는 완만하게 감소하면서 단호박 분말 $5 \%$, $15 \%$ 조건에서 각각 $\mathrm{pH} 3.71$ 및 $\mathrm{pH} 3.85$ 로 유사한 값을 나타내었다. 단호박 젖산 발효물의 산도는 단호박 분말 첨 가량 및 발효 시간이 길어짐에 따라 증가하는 경향을 보였 으며, 이는 젖산균에 의해 생성된 lactic acid를 포함하는 대사산물이 생성되어 산도 증가에 영향을 주는 것으로 사료 되었다. 단호박 분말 $5 \%, 10 \%$ 첨가의 경우에 젖산 발효 1 일에 단호박 젖산 발효물의 산도는 급격하게 증가된 후 발효기간에 따라 완만하게 증가하면서 발효 3일에 각각 $0.94 \%, 1.18 \%$ 를 나타내었으며, 단호박 분말 $15 \%$ 의 경우에

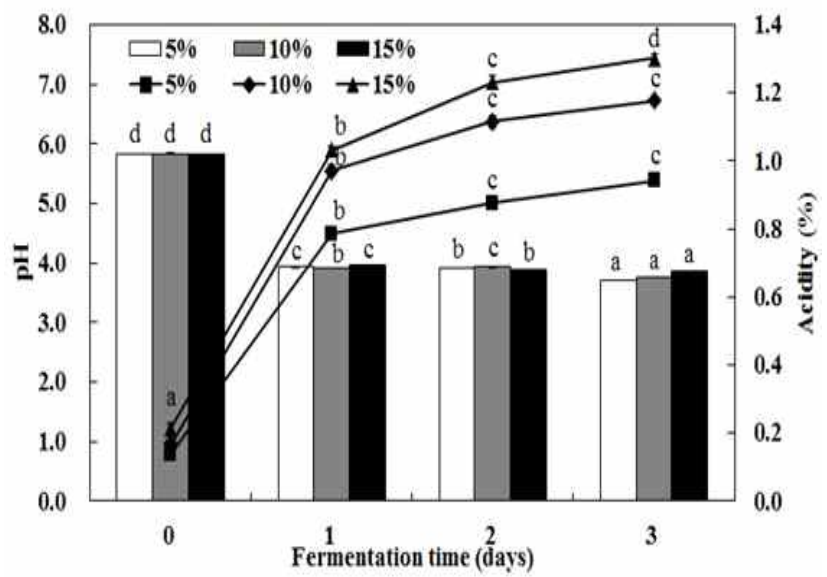

Fig. 1. Changes in $\mathrm{pH}$ and acidity of sweet pumpkin paste fermented by $L$. mesenteroides SM.

Values are means \pm SD.

${ }^{a-d}$ Means in the same row with different superscript letters are significantly different by Duncan's multiple range test $(\mathrm{p}<0.05)$. 
발효물의 산도가 $1.30 \%$ 로 가장 높은 값을 보였다. 이는 이상발효 젓산균의 산생성 특징으로서 김치의 대표적인 젖산균인 L mesenteroides는 포도당과 과당과 같은 발효성 당으로부터 젖산 이외에 acetate, 에탄올 및 만니톨을 생성 하는 것으로 보고되었다(26). 단호박 젖산 발효물의 생균수 변화는 Fig. 2에서 나타낸 것처럼 단호박 분말의 첨가 농도 에 의존적으로 생균수가 증가하는 경향을 보였다. 단호박 분말 $5 \%$ 첨가보다는 $10 \%, 15 \%$ 경우에 젖산균 생균수는 증가되면서 발효 1 일 후에 각각 $6.2 \times 10^{8} \mathrm{CFU} / \mathrm{mL}, 9.2 \times 10^{8}$ $\mathrm{CFU} / \mathrm{mL}$ 로 높은 생균수를 나타내었으며, 발효 3일까지 젖 산균의 생균수가 감소하는 경향을 보였다. 반면에 단호박 분말 $5 \%$ 첨가 조건에서는 발효 1 일에 $2.5 \times 10^{8} \mathrm{CFU} / \mathrm{mL}$ 으로 가장 낮은 생균수를 보이면서 발효기간 동안에 완만하게 증가하는 경향을 보였다. 따라서 단호박 분말을 원료로 이 용한 젖산균 발효에서 단호박 분말의 농도에 의존적으로 젓산의 생성과 생균수가 증가하는 것으로 보이며, 이는 단 호박 분말 첨가량에 따른 영양성분의 강화와 연관이 있는 것으로 사료되었다. 특히, 젖산발효에서 유기산의 생성으 로 인한 $\mathrm{pH}$ 저하 등의 생육환경의 변화를 초래하며, 동시에 불충분한 영양성분으로 영양 요구성이 높은 젖산균의 생육 이 억제되는 것으로 사료되었다. 김치의 숙성균으로 알려 진 Leuconostoc sp는 김치 발효 중기에 왕성하게 작용하여 유기산, 탄산가스 등을 생성하면서 혐기적인 발효환경을 조성하는 데 기여하며, 김치 발효 후기에는 주된 젖산 생성 균인 Lactobacillus plantarum균이 왕성하게 산생성에 작용 하는 것으로 보고되었다(27). 김치 젓산균을 이용한 대두 요구르트 제조시에 발효 후기에 생균수의 감소는 균의 생육 이 억제되기 시작하는 사멸기에 도달했기 때문이라는 $\mathrm{Kim}$ (25)의 연구보고가 있었다. 단호박을 이용한 젓산발효의 경우에 발효 3 일 후에도 단호박 젖산 발효물에 식물성 젖산

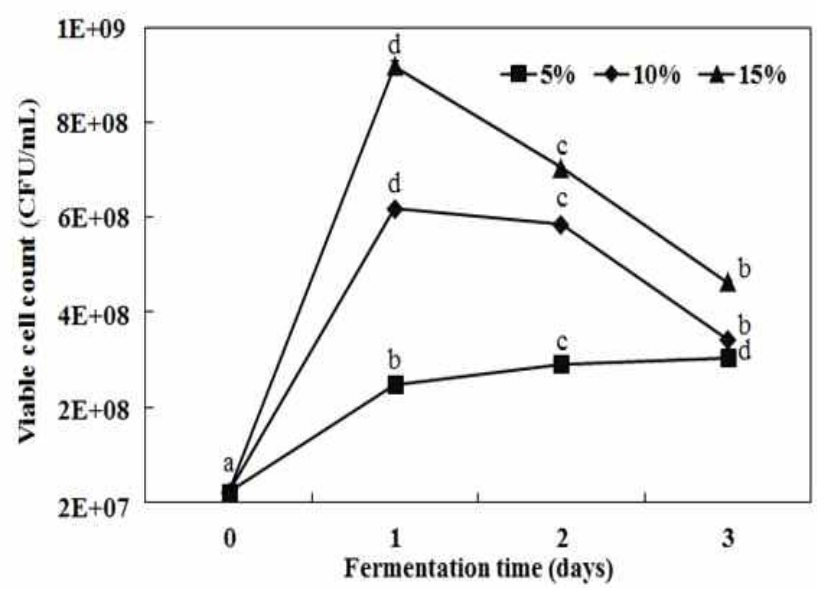

Fig. 2. Changes in viable cell number of sweet pumpkin paste fermented with $L$. mesenteroides SM.

Values are means \pm SD.

${ }^{a-1}$ Means in the same row with different superscript letters are significantly different by Duncan's multiple range test $(\mathrm{p}<0.05)$.
균의 생균수는 $3.0 \times 10^{9} \mathrm{CFU} / \mathrm{mL}$ 이상으로 비교적 높은 생균 수 값을 유지하는 것으로 나타났으며, 이는 젖산균 probiotic 가 강화된 단호박 젖산 발효물의 생산이 가능하다고 판단되 었다.

\section{단호박 젖산 발효물의 색도 측정}

단호박에 존재하는 지용성의 $\beta$-carotene성분은 고유한 황색을 나타내는데 기여하며, 발효중에 발효물의 색상변화 를 측정하였다. 단호박 저장 기간 중에 색소의 안정성에 관한 연구에서 단호박의 주된 색소는 $\beta$-carotene을 포함하 여 lutein, violaxanthin 등이 존재한다고 보고하였다(28).

단호박 분말의 명도와 적색을 나타내는 $\mathrm{L}$ 값, $\mathrm{a}$ 값은 각각 $46.07,0.54$ 였으며, 황색을 나타내는 $\mathrm{b}$ 값은 23.95 의 높은 값을 보이면서 고유한 황색을 나타내었다. 발효 초기 $15 \%$ 단호박 분말 paste의 명도 L값은 25.02로 가장 높았으며, 발효 3일 동안에 약간 증가하는 경향을 보였다. 그러나 단호 박 분말을 $5 \%$ 수준으로 첨가하였을 때 명도 값은 21.91로 낮은 값을 보였으며, 발효 3일 동안에 약간 증가하는 경향을 보였다. 단호박 젖산 발효물의 적색도 값(a)과 황색도 값(b) 은 단호박 분말 첨가량이 높아질수록 증가하였고, $15 \%$ 단 호박 분말 첨가 시에 발효 초기에 각각 $\mathrm{a}$ 값 $4.66, \mathrm{~b}$ 값 13.35 을 보였으며, 발효 기간 동안에 $\mathrm{a}, \mathrm{b}$ 값은 큰 차이가 없는 것으로 나타났다(Table 1).

Table 1. Change in color of various sweet pumpkin paste fermented with $L$. mesenteroides SM

\begin{tabular}{cccccc}
\hline & \multirow{2}{*}{$\operatorname{SPP}^{1)}(\%)$} & \multicolumn{4}{c}{ Fermentation time (days) } \\
\cline { 3 - 6 } & & 0 & 1 & 2 & 3 \\
\hline & 5 & $21.91 \pm 0.04^{2 / 23)}$ & $25.65 \pm 0.26^{\mathrm{d}}$ & $23.86 \pm 0.02^{\mathrm{c}}$ & $22.75 \pm 0.14^{\mathrm{b}}$ \\
$\mathrm{L}$ & 10 & $24.60 \pm 0.09^{\mathrm{b}}$ & $26.20 \pm 0.03^{\mathrm{d}}$ & $25.28 \pm 0.04^{\mathrm{c}}$ & $23.91 \pm 0.05^{\mathrm{a}}$ \\
& 15 & $25.02 \pm 0.13^{\mathrm{a}}$ & $26.35 \pm 0.27^{\mathrm{b}}$ & $26.25 \pm 0.31^{\mathrm{b}}$ & $26.24 \pm 0.11^{\mathrm{b}}$ \\
\hline & 5 & $0.78 \pm 0.01^{\mathrm{b}}$ & $0.57 \pm 0.02^{\mathrm{a}}$ & $0.57 \pm 0.13^{\mathrm{a}}$ & $1.00 \pm 0.07^{\mathrm{c}}$ \\
$\mathrm{a}$ & 10 & $2.46 \pm 0.03^{\mathrm{a}}$ & $2.82 \pm 0.18^{\mathrm{c}}$ & $2.53 \pm 0.06^{\mathrm{ab}}$ & $2.66 \pm 0.05^{\mathrm{bc}}$ \\
& 15 & $4.66 \pm 0.13^{\mathrm{d}}$ & $3.66 \pm 0.11^{\mathrm{b}}$ & $3.20 \pm 0.10^{\mathrm{a}}$ & $4.14 \pm 0.02^{\mathrm{c}}$ \\
\hline & 5 & $8.71 \pm 0.09^{\mathrm{a}}$ & $10.09 \pm 0.03^{\mathrm{b}}$ & $10.06 \pm 0.13^{\mathrm{b}}$ & $10.04 \pm 0.07^{\mathrm{b}}$ \\
$\mathrm{b}$ & 10 & $11.21 \pm 0.10^{\mathrm{a}}$ & $12.62 \pm 0.06^{\mathrm{c}}$ & $11.70 \pm 0.19^{\mathrm{b}}$ & $11.10 \pm 0.03^{\mathrm{a}}$ \\
& 15 & $13.35 \pm 0.08^{\mathrm{d}}$ & $11.53 \pm 0.35^{\mathrm{b}}$ & $10.24 \pm 0.15^{\mathrm{a}}$ & $12.34 \pm 0.11^{\mathrm{c}}$ \\
\hline
\end{tabular}

${ }^{1)}$ SPP, Sweet pumpkin powder.

${ }^{2)}$ Values are means \pm SD.

${ }^{3) \text { ard }}$ Means in the same row with different superscript letters are significantly different by Duncan's multiple range test $(\mathrm{p}<0.05)$.

발효 기간에 따른 적색도 및 황색도의 유사한 값을 유지 함에 따라서 단호박 분말을 젓산균에 의한 3 일 동안의 발효 기간에 따른 carotenoid색소는 비교적 안정한 것으로 사료 되었다. Carotenoid 색소의 대표적인 성분인 $\beta$-carotene은 저장온도가 높을수록 불안정하며, $\mathrm{pH}$ 3에서 색소 파괴속도 
가 높다고 보고되었다(30). 그러나 단호박 분말의 젖산발효 를 비교적 낮은 $25^{\circ} \mathrm{C}$ 에 수행함으로서 $\beta$-carotene색소의 파 괴가 최소화 되면서 발효 3 일 동안에 제조된 단호박 젖산 발효물은 carotenoid 색소가 비교적 안정화하면서 고유한 노란색을 유지할 수 있었다.

\section{Dextran 함량 측정}

식물성 젖산균 Leuconostoc sp은 설탕을 포함하는 배지에 서 세포외로 분비되는 dextransucrase효소의 촉매 작용에 의해서 수용성 및 불용성 dextran을 합성한다고 보고되었다 (25). 탄소원으로 설탕과 단호박 분말 첨가량에 따른 젖산 발효물에서 생성된 수용성 및 불용성 dextran 함량을 각각 Fig. 3에 나타내었다. 최근 김치 젖산균 Leu. mesenteroides 에 의한 고분자 점질물 dextran의 생산은 탄소원으로 첨가 된 설탕의 농도에 의해서 크게 의존하며, $20 \%$ 농도의 설탕 농도에서 dextran 생산이 최적인 것이 보고되었다(25).

단호박 젖산 발효물의 설탕농도 $20 \%$ 조건에서 발효 기간 에 따른 수용성 및 불용성 dextran 함량은 증가하면서 발효 2 일에 가장 높은 값을 보인 후에 완만한 감소를 나타내었다. 특히, 단호박 분말 첨가량에 따라 dextran 생성에 차이가 있는 것으로 나타났다. 수용성 dextran 함량은 발효 2일째 단호박 분말 $5 \%, 10 \%, 15 \%$ 에서 각각 $4.7 \%, 4.8 \%, 4.3 \%$ 수준으로 비슷하게 생성되었으며, 발효 3일에는 약간 감소 한 값을 나타내었다. 불용성 dextran 함량은 수용성 dextran 에 비해 생성량이 높았으며, 발효 2일에 가장 높은 dextran 함량을 보이면서 첨가되는 단호박 분말 첨가농도에 크게 의존적으로 증가하는 경향을 보였다. 발효 2 일째 단호박 분말 $15 \%$ 에서 $9.3 \%$ 로 가장 높게 나타났고 이후로는 약간 감소하는 경향을 보였다. 단호박 분말 $5 \%, 10 \%$ 에서도 발효 2 일째 불용성 dextran 생산량이 각각 $3.4 \%, 6.5 \%$ 를 나타

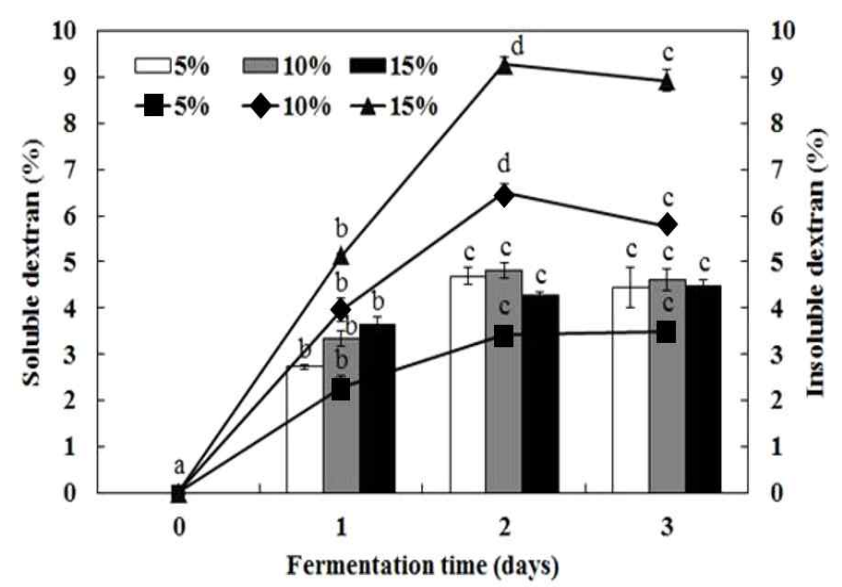

Fig. 3. Changes in dextran contents of sweet pumpkin pastes fermented with $L$. mesenteroides SM.

Values are means $\pm \mathrm{SD}$.

${ }_{\text {a-d }}$ Means in the same row with different superscript letters are significantly different by Duncan's multiple range test $(p<0.05)$.
내었으며, 발효 3 일에 조금 감소하는 경향을 보였다. 단호 박 분말의 젖산 발효 2 일 동안 생성된 총 dextran 함량은 단호박 분말 $15 \%$ 조건에서 $13.6 \%$ 로 가장 높았으며, 단호박 분말 $10 \%, 5 \%$ 가 각각 $11.3 \%, 8.1 \%$ 수준으로 단호박 분말 농도에 의존적으로 증가하였다.

식물성 젖산균을 이용하여 제한배지조건에서 dextran 생 성을 위한 젖산발효에서 발효 온도에 따라 수용성 및 불용 성 dextran 생성에 차이가 있었으며, 발효 $25^{\circ} \mathrm{C}$ 에서 3 일 동 안 발효과정에서 불용성 dextran이 수용성 dextran 보다 높 은 함량을 보고(31)한 연구와 유사한 결과를 나타내었다. 일반적으로 젖산균이 생산하는 고분자 다당류 dextran은 점조를 증진시키면서 식품의 물성개량제로 널리 이용되고 있지만, 최근 Leuconostocaceae에 속하는 젓갈 유래 젖산균 Weissella cibaria가 생산하는 dextran이 Bifidobacterium 균 주에 생육을 촉진하는 probiotic로서 가능성이 보고되었다 (32).

Leu. mesenteroides SM과 제한배지를 이용한 dextran 생 성에서 $\mathrm{YE}$ 농도 첨가에 따라 큰 차이가 있음을 보고하였으 며, 최종 발효물의 점조도 값이 $38 \mathrm{~Pa} \cdot \mathrm{s}$, 수용성 및 불용성 dextran 함량이 각각 $32.42,82.08 \mathrm{~g} / \mathrm{kg}$ 으로 총 dextran 함량 이 $128.50 \mathrm{~g} / \mathrm{kg}$ 으로 높은 값을 나타내었다(25). 단호박 분말 $15 \%$ 조건에서 총 dextran 함량이 $13.56 \%$ 로 높게 생성된 것은 제한배지에 비해서 단호박 배지에 포함된 영양성분, 발효환경 등의 차이에 기인한 것으로 판단되었다. 특히, 치즈 제조시에 부산물인 유청을 원료로 이용한 젓산균의 발효과정에서 $\mathrm{YE}$ 의 첨가는 젖산균의 생육과 젖산생성에 영향을 미치는 것으로 보고되었다(33). 동일한 식물성 젖산 균을 이용한 제한배지 조건에서 $\mathrm{YE}$ 첨가량이 $0.5 \%$ 수준으 로 첨가하였을 때 발효물의 점조성이 급격하게 증가하였으 며, $\mathrm{YE}$ 첨가량이 증가하면서 발효물의 점조성이 완만하게 증가하는 경향을 보고하였다(25). 그러나 단호박을 이용한 젖산 발효 시에 영양성분 $\mathrm{YE}$ 첨가량이 높은 경우에 최종 발효제품의 맛과 냄새 등의 기호성이 감소하는 경향이 있어 서 최소량의 $\mathrm{YE}$ 를 첨가하는 것이 필요하였다. 따라서 $\mathrm{YE}$ $0.5 \%$ 를 첨가한 조건에서 단호박 분말 $15 \%$ 를 함유한 페이 스트를 이용한 젖산발효가 고분자 점질물 dextran 생성에 가장 적합한 것으로 판단되었다.

\section{Sucrose 소진율, fructose 및 mannitol 함량 측정}

젖산균 Leuconostoc $\mathrm{sp}$ 는 설탕을 탄소원으로 이용하여 점질물 dextran을 생성하며, 동시에 당알코올인 만니톨을 생성하는 것으로 알려져 있어, 단호박 젖산 발효물의 설탕 소진율 및 만니톨 함량 변화는 Table 2에 나타내었다. Leuconostoc 균주가 생산하는 dextransucrase 효소 작용에 의해 기질인 설탕은 포도당과 과당으로 가수분해 되며, 동 시에 dextran 중합체 형성과 mannitol dehydrogenase(MDH) 효소 작용에 의해서 유리된 과당은 전자 수용체(electron 
acceptor) 역할을 하여 mannitol로 환원된다(34). 젖산발효 동안에 첨가된 설탕의 소진율은 단호박 분말농도에 의존적 으로 증가하면서, 발효 1 일에 단호박 분말 $5 \%$ 는 $84.59 \%$ 소진율을 보였지만, $10 \%, 15 \%$ 에서 모두 $100 \%$ 의 소진율을 나타내었다. 특히 발효 2 일 이후로는 단호박 분말의 첨가 농도에 관계없이 모든 조건에서 $100 \%$ 소진율을 나타내었 으며, 이러한 결과는 설탕 $20 \%$ 를 포함하는 당근주스에서 식물성 젖산균을 이용한 dextran 생성에서 발효 1일에 $100 \%$ 소진율을 보인다는 보고(22)와 유사한 결과를 나타내었다.

Table 2. Changes in sucrose reduction ratio, fructose and mannitol contents of sweet pumpkin paste fermented by $L$. mesenteroides SM

\begin{tabular}{ccccc}
\hline & \multirow{2}{*}{$\begin{array}{c}\text { SPP }^{1)} \\
(\%)\end{array}$} & \multicolumn{3}{c}{ Fermentation time (days) } \\
\cline { 3 - 5 } & 5 & 84.59 & 100.00 & 100.00 \\
\hline $\begin{array}{c}\text { Sucrose } \\
\text { reduction ratio } \\
(\%)\end{array}$ & 10 & 100.00 & 100.00 & 100.00 \\
& 15 & 100.00 & 100.00 & 100.00 \\
\hline & 5 & $1.59 \pm 0.03^{2) b 3)}$ & $2.12 \pm 0.01^{\mathrm{c}}$ & $2.17 \pm 0.01^{\mathrm{c}}$ \\
Fructose & 10 & $2.16 \pm 0.02^{\mathrm{ab}}$ & $2.10 \pm 0.01^{\mathrm{b}}$ & $2.18 \pm 0.01^{\mathrm{c}}$ \\
$(\%)$ & 15 & $2.38 \pm 0.03^{\mathrm{d}}$ & $2.21 \pm 0.02^{\mathrm{c}}$ & $1.76 \pm 0.06^{\mathrm{b}}$ \\
\hline & 5 & $2.19 \pm 0.01^{\mathrm{b}}$ & $2.25 \pm 0.00^{\mathrm{c}}$ & $2.31 \pm 0.01^{\mathrm{d}}$ \\
Mannitol & 10 & $2.29 \pm 0.02^{\mathrm{b}}$ & $2.66 \pm 0.01^{\mathrm{c}}$ & $2.84 \pm 0.02^{\mathrm{d}}$ \\
$(\%)$ & 15 & $2.58 \pm 0.01^{\mathrm{b}}$ & $2.85 \pm 0.01^{\mathrm{c}}$ & $3.11 \pm 0.01^{\mathrm{d}}$ \\
\hline
\end{tabular}

${ }^{1)}$ SPP, Sweet pumpkin paste.

${ }^{2)}$ Values are means $\pm \mathrm{SD}$.

${ }^{3) a d}$ Means in the same row with different superscript letters are significantly different by Duncan's multiple range test $(\mathrm{p}<0.05)$.

젖산균에 의한 설탕의 대사과정에서 이당류 설탕의 분해 산물인 과당은 발효 1 일에 단호박 분말의 첨가 농도에 따라 의존적으로 생성되는 것으로 나타났다. 과당의 함량은 단 호박 분말 $5 \%, 10 \%$ 에서는 발효 시간이 증가함에 따라 계속 적으로 증가하는 경향을 보였다. 그러나 단호박 분말 $15 \%$ 경우는 발효 1 일에 $2.38 \%$ 로 가장 높은 값을 보였으나 발효 기간 동안 감소되면서 발효 3 일에 $1.76 \%$ 로 가장 낮은 값을 나타내었다.

젖산균 발효 과정에서 생성된 만니톨 함량은 단호박 분 말 첨가농도 및 발효기간이 증가하면서 완만하게 증가하는 경향을 보였다. 발효 1 일에 단호박 젖산 발효물의 만니톨 함량은 단호박 분말 첨가 농도 증가에 따라서 각각 $2.19 \%$, $2.29 \%, 2.58 \%$ 로 높은 값을 보였으며, 그 이후에는 발효 3 일 동안에 완만하게 증가되었다. 특히, 단호박 분말 $15 \%$ 첨가 조건에서 발효 3일에 가장 높은 $3.11 \%$ 만니톨 함량을 보였 으며, 단호박 분말 $5 \%, 10 \%$ 는 각각 만니톨 $2.31 \%, 2.84 \%$ 로 비교적 낮은 값을 나타났다. 따라서 $15 \%$ 단호박 분말 조건 에서 젖산 발효 3 일에 잔존하는 과당의 함량이 가장 적었으 며, 이는 과당의 일부가 만니톨로 전환된 것으로 사료되었
다. 김치 젖산균인 Leuconosstoc sp는 설탕과 과당을 만니톨 생성의 기질로 이용하였으며, $5 \%$ 과당을 기질로 사용할 경우에 $52 \%$ 수율로 만니톨 생성을 보고하였다(35).

이상발효 젖산균인 L mesenteroides는 과당을 발효성 당 으로 이용하며 동시에 당 대사과정에서 전자 전달자 (electron acceptor) 역할을 수행하면서 만니톨을 생성하는 것으로 보고되었다(26). 따라서 단호박의 발효 중에 설탕의 가수분해물로 생성된 과당이 젖산균의 발효성 당과 동시에 만니톨 생성에 이용되는 것으로 사료되었다.

제한배지를 이용하여 식물성 젖산균 L. mesenteroides $\mathrm{SM}$ 과 L. plantarum의 혼합발효를 통한 dextran, 만니톨, GABA생산 연구에서 $L$ mesenteroides SM에 의한 젖산발효 2 일에 설탕의 소진율과 만니톨 함량은 각각 $78 \%, 1.67 \%$ 로 비교적 낮은 값을 보였으며, 과당은 $2.18 \%$ 가 함유하는 것으 로 보고되었다(36). 이상의 연구결과를 바탕으로 단호박 분말을 젖산발효의 원료로 사용하는 경우에 단기간에 효과 적으로 젖산발효가 진행되어 발효성 당으로 첨가되는 설탕 이 $100 \%$ 전환되면서 비교적 높은 만니톨을 생산되는 것으 로 판단되었다.

\section{점조도 측정}

단호박 젖산 발효물은 점조성을 갖는 푸딩형태를 나타내 면서 측정된 점조도 변화는 Fig. 4와 같다. 단호박 분말 첨가량이 높을수록 초기 점조도 값이 증가하는 경향을 보이 면서, 단호박 분말 $10 \%$ 수준에서는 $4.8 \mathrm{~Pa} \cdot \mathrm{s}^{\mathrm{n}}$ 이하의 낮은 점조도 값을 보였으며, 단호박 분말 $15 \%$ 수준으로 첨가 시에 점조도 값은 $48.6 \mathrm{~Pa} \cdot \mathrm{s}^{\mathrm{n}}$ 으로 크게 증가하였다. 이는 단호박에 존재하는 전분성분이 열처리에 따라 호화됨으로 서 단호박 농도에 의존적으로 점조도 값이 크게 증가하는 것으로 사료되었다. 특히 단호박 분말 $15 \%$ 조건에서 젓산 발효 1일에 $75.1 \mathrm{~Pa} \cdot \mathrm{s}^{\mathrm{n}}$ 에서 2일째 $173.1 \mathrm{~Pa} \cdot \mathrm{s}^{\mathrm{n}}$ 으로 점조도 값이 급격히 증가하였으며, 특히 발효 3일째에는 점조도가 더 증가하여 $188.8 \mathrm{~Pa} \cdot \mathrm{s}^{\mathrm{n}}$ 으로 매우 높은 값을 나타내었다. 이는 당근 주스 또는 제한배지에서 식물성 젖산균을 이용한 dextran 생성에 따른 점조도 값이 각각 $3.3 \mathrm{~Pa} \cdot \mathrm{s}^{\mathrm{n}}$ 과 43.0 $\mathrm{Pa} \cdot \mathrm{s}^{\mathrm{n}}$ 인 것으로 보고(22,25)된 것과 비교하였을 때 매우 높 은 점조도 값으로 사료되었다. 식물성 젖산균에 의한 dextran 생성 연구에서 발효 1 일에 점조도가 급격히 증가하 면서 발효 2일부터 완만하게 증가하는 경향을 보고한바 있었다(36). 단호박 분말 $15 \%$ 를 이용하여 $20 \%$ 설탕 존재 하에서 식물성 젖산균에 의한 발효는 단기간에 효과적으로 수행되면서 고분자 점질물인 dextran을 생성함으로서 높은 점조성을 갖는 단호박 젖산 발효물을 생산할 수 있었다. 이는 동물성 젤라틴 등을 활용하여 제조되는 푸딩과 유사한 물성적 특성을 가지며, 동시에 기능성 성분이 강화된 단호 박 젖산 발효물을 제조할 수 있었다. 


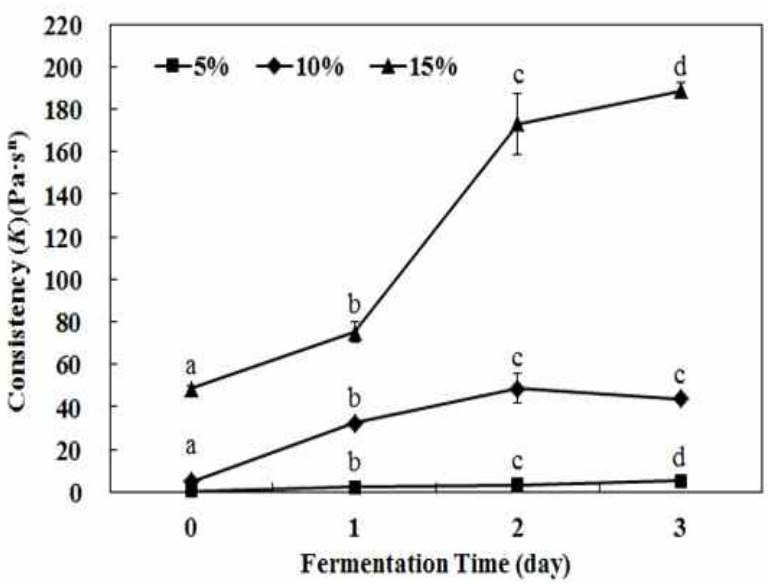

Fig. 4. Changes in consistency of sweet pumpkin paste fermented with $L$. mesenteroides SM.

Values are means \pm SD.

${ }^{\text {a-d }}$ Means in the same row with different superscript letters are significantly different by Duncan's multiple range test $(\mathrm{p}<0.05)$.

관능평가

관능평가는 3 일 동안 발효한 단호박 젖산 발효물을 5점 척도법을 이용하여 얻어진 결과는 Table 3에서 나타내었다. 단호박 분말 $5 \%$ 에서는 단맛을 제외한 모든 군에서 단호박 분말 $10 \%, 15 \%$ 첨가군에 비하여 유의적으로 낮은 점수를 획득하였다. 색과 단맛은 단호박 분말 $10 \%, 15 \%$ 에서 4.80 점으로 높은 평가를 받았으며, 신맛은 단호박 분말 $5 \%$ 가 3.20점으로 낮게 평가되었는데 이는 단호박 분말 첨가량이 높을수록 단호박 맛을 더 느낄 수 있기 때문에 상대적으로 신맛을 보완해주는 것으로 판단되었다. 쓴맛은 상대적으로 모든 조건에서 낮은 평가를 받았으며, 특히 단호박 분말 $5 \%$ 에서 2.60 점으로 낮은 평가를 받았으며, 조직감은 단호 박 분말 $15 \%$ 에서 4.80 점으로 가장 좋은 평가를 받았다. 전반적 기호도에서는 단호박 분말 $5 \%$ 가 3.20 점으로 가장 낮았고, 단호박 분말 $10 \%$ 이상 첨가 시에는 유의적인 차이 를 보이지 않는 것으로 나타났다.

Table 3. Sensory evaluation of sweet pumpkin paste fermented with $L$. mesenteroides SM

\begin{tabular}{|c|c|c|c|}
\hline & \multicolumn{3}{|c|}{$\operatorname{SPP}^{1)}(\%)$} \\
\hline & 5 & 10 & 15 \\
\hline Color & $4.00 \pm 0.71^{2) a 3)}$ & $4.80 \pm 0.45^{b}$ & $4.80 \pm 0.45^{\mathrm{b}}$ \\
\hline Sweetness & $4.60 \pm 0.55^{\mathrm{a}}$ & $4.80 \pm 0.45^{\mathrm{a}}$ & $4.80 \pm 0.45^{\mathrm{a}}$ \\
\hline Sourness & $3.2045^{\mathrm{a}} \pm 0$. & $4.40 \pm 0.55^{\mathrm{b}}$ & $4.60 \pm 0.55^{\mathrm{b}}$ \\
\hline Bitterness & $2.60 \pm 0.55^{\mathrm{a}}$ & $3.60 \pm 0.55^{b}$ & $3.80 \pm 0.45^{\mathrm{b}}$ \\
\hline Texture & $2.40 \pm 0.55^{\mathrm{a}}$ & $4.40 \pm 0.55^{\mathrm{b}}$ & $4.80 \pm 0.45^{\mathrm{b}}$ \\
\hline Overall acceptability & $3.20 \pm 0.45^{\mathrm{a}}$ & $4.00 \pm 0.71^{b}$ & $4.60 \pm 0.55^{b}$ \\
\hline
\end{tabular}

이상의 결과를 종합하였을 때 단호박 분말을 이용한 젖 산 발효물을 제조 시 일반 푸딩제품이 가지는 조직감과 유사한 물성을 위해서 단호박 분말을 $15 \%$ 수준으로 첨가하 는 것이 필요하였다. 특히, 단호박 분말 $15 \%$ 함유한 젓산 발효물은 많은 수의 probiotic을 함유하며 고유한 색상과 맛, 품질에서 가장 양호한 기호도를 나타내었다.

\section{요 약}

단호박 분말을 이용하여 식물성 젖산균의 발효 최적화를 통한 점질물 dextran, 만니톨을 생산함으로서 물성과 맛이 개선된 푸딩형태의 단호박 젖산 발효물을 제조하였다. 단 호박 농도에 따라서 젖산 발효물에 영향을 주었으며, 단호 박 분말 $15 \%$ 조건이 가장 양호한 물리화학적 특성을 보였 다. $25^{\circ} \mathrm{C}$ 에서 3 일 동안 발효를 수행하였을 때 $15 \%$ 단호박 분말의 젖산 발효물의 $\mathrm{pH}$, 산도는 각각 $3.85,1.30 \%$ 이었으 며, 생균수는 $4.64 \times 10^{9} \mathrm{CFU} / \mathrm{mL}$ 로 높은 값을 나타내었다. 단호박 분말 paste의 발효 초기에 $\mathrm{L}$ 값 $25.02, \mathrm{a}$ 값 $4.66, \mathrm{~b}$ 값 13.35 를 나타내었으며, 발효가 진행되면서 $\mathrm{L}$ 값을 제외하고 감소하는 경향을 보였다. $10 \%, 15 \%$ 단호박 분말의 발효물 은 발효 1 일에 설탕의 소진율 $100 \%$ 를 보였으며, 발효 3 일에 불용성 dextran을 각각 $5.6 \%, 8.9 \%$ 를 보였으며, 수용성 dextran은 $4.5 \%$ 수준으로 유사하였다. $15 \%$ 단호박 분말의 3 일 후에 발효물에 과당과 만니톨 함량은 각각 $1.76 \%$, $3.11 \%$ 를 나타내었다. $15 \%$ 단호박 젖산 발효물의 점조도는 초기 $48.6 \mathrm{~Pa} \cdot \mathrm{s}^{\mathrm{n}}$ 로서 가장 높은 값을 보였으며, 발효 1 일 $75.1 \mathrm{~Pa} \cdot \mathrm{s}^{\mathrm{n}}$ 에로 증가하였으며, 발효 3 일에는 $188.8 \mathrm{~Pa} \cdot \mathrm{s}^{\mathrm{n}}$ 으로 크게 증가하면서 푸딩 형태의 물성을 나타내었다. 단호박 젖산 발효물의 관능평가를 통해서 $15 \%$ 단호박 젖산 발효물 이 색, 단맛, 조직감에서 높은 점수로 평가되었다. 결론적으 로 $15 \%$ 단호박 분말과 $20 \%$ 설탕혼합액을 이용하여 3 일 동안 젖산 발효시킴으로서 설탕은 $100 \%$ 전환되었으며, protiotic 생균 $4.6 \times 10^{9} \mathrm{CFU} / \mathrm{mL}$ 을 포함한 만니톨, 점질물 dextran의 생성을 통해서 기능성, 맛과 조직감이 강화된 푸 딩형태의 단호박 젖산발효제품을 개발할 수 있었다.

\section{감사의 글}

본 결과물은 농림축산식품부의 재원으로 농림수산식품 기술기획평가원의 기술사업화지원사업(No 314082-3)지원 과 지식경재부 지원 계명대학교 전통미생물자원개발 및 산업화연구센터에 의해 연구되었음

\section{References}

1. Mentean E, Muntean N, Duda MM (2013) Cucurbita 
maxima Duch. as a medicinal plant. Hop Med Plants, 21, 41-42

2. Heo SJ, Kim JH, Kim JK, Moon KD (1998) Processing of purees from pumpkin and sweet-pumpkin. Korean $\mathrm{J}$ Food Soc Food Preserv, 5, 172-176

3. Heo SJ, Kim JH, Kim JK, Moon KD (1998) The comparison of food constituents in pumpkin and sweet-pumpkin. J Korean Soc Food Cult, 13, 91-96

4. Kim SR, Ha TY, Song HN, Kim YS, Park YK (2005) Comparison of nutritional composition and antioxidative activity for kabocha squash pumpkin. Korean J Food Sci Technol, 37, 171-177

5. Whang HJ (1999) The change of carotenoid pigment in Korea pumpkin using drying. Food Eng Prog, 4, 214-219

6. Kuwaki S, Nakajima N, Tanaka H, Ishihara K (2012) Plant-based paste fermented by lactic acid bacteria and yeast: functional analysis and possibility of application to functional foods. Biochemistry Insights, 5, 21-29

7. Kohajdova Z, Karovicova J, Greifova M (2006) Lactic acid fermentation of some vegetable juices. J Food Nutr Res, 45, 115-119

8. Semjonovs P, Denina I, Fomina A, Sakirova L, Auzina L, Patetko A, Upite D (2013) Evaluation of Lactobacillus reuteri strains for pumpkin (Cucurbita pepo L.) juice fermentation. Biotechnology, 12, 202-208

9. Sun Y, Hayakawa S, Ogawa M, Izumori K (2007) Antioxidant properties of custard pudding dessert containing rare boxose, D-psicose. Food Control, 18, 220-227

10. Dogan M, Ersoz NB, Toker OS, Kaya Y, Canylmaz E (2014) Optimization of gum combination for instant pudding based on creep and recovery parameters by mixture design approach. Eur Food Res Technol, 238, 47-58

11. Choi EH, Kim DS, Choi SK, Park KB (2013) Optimization and quality characteristics of balsamic vinegar jelly with various gelling agents. Culinary Science \& Hospitality Research, 19, 155-163

12. Moon HK, Lee SW, Moon JN, Yoon SJ, Lee S, Kim GY (2012) Quality characteristics of Jelly added with mulbery juice. Korean J Food Cook Sci, 28, 797-804

13. Cross ML, Stevenson LM, Gill HS (2001) Anti-allergy properties of fermented foods: an important immuno regulatory mechanism of lactic acid bacteria?. Int Immunopharmacol, 1, 891-901

14. Parvez S, Malik KA, Kang SA, Kim HY (2006) Probiotics and their fermented food products are beneficial for health. J Appl Microbiol, 100, 1171-1185

15. Vijayakumar J, Aravindan R, Viruthagiri T (2008) Recent trends in the production, purification and application of lactic acid. Chem Biochem Eng Q, 22, 245-264

16. Hwang SK, Hong JT, Jung KH, Chang BC, Hwang KS, Shin JH, Yim SP, Yoo SK (2008) Process optimization of dextran production by Leuconostoc sp. strain YSK. isolated from fermented kimchi. J Life Sci, 18, 1377-1383

17. Santos M, Teixeira JA, Rodrigues A (2000) Production of dextransucrase, dextran and fructose from sucrose using Leuconostoc mesenteroides NRRL B512(f). Biochem Eng J, 4, 177-188

18. Son MJ, Jang EK, Kwon OS, Seo JH, Kim IJ, Lee IS, Park SC, Lee SP (2008) Characterization of dextran produced from Leuconostoc citreum S5 strain isolated from Korean fermented vegetable. Eur Food Res Technol, 226, 697-706

19. Kim CY, Lee JH, Kim BH, Yoo SK, Seo ES, Chos KS, Day DF. Kim DM (2002) Production of mannitol using Leuconostoc mesenteroides NRRL B-1149. Biotechnol Bioprocess Eng, 7, 234-236

20. Saha BC, Racine FM (2011) Biotechnological production of mannitol and its applications. Appl Microbiol Biotechnol, 89, 879-891

21. Ghosa S, Sudha ML (2012) A review on polyols: new frontiers for health-based bakery products. Int $\mathrm{J}$ Food Sci Nutr, 63, 372-379

22. Jo SJ, Oh SM, Jang EK, Hwang K, Lee SP (2008) Physicochemical properties of carrot juice fermented by Leuconostoc mesenteroides SM. J Korean Soc Food Sci Nutr, 37, 210-216

23. Kang TH, Jung SJ, Kang SA, Jang KH, Jang EK, Kim CH, Kim IH, Kim SH, Rhee SK, Chun UH (2002) Preparation of levan oligosaccharides by acid hydrolysis and its application in growth of lactic acid-producing bacteria. KSBB J, 17, 137-141

24. Kim DS, Thomas S, Fogler HS (2000) Effects of $\mathrm{pH}$ and trace minerals on long-term starvation of Leuconostoc mesenteroides. Appl Environ Microbiol, 66, 976-981

25. Kim JE, Whang K, Lee SP (2012) Physicochemical properties of dextran produced by Leuconostoc mesenteroides SM according to concentration of yeast extract and its modulation of rheological properties. Korean J Food Sci Technol, 44, 216-223

26. Wisselink HW, Weusthuis RA, Eggink G, Hugenholtz J, Grobben GJ (2002) Mannitol productin by lactic acid bacteria: a review. Int Dairy J, 12, 151-161 
27. Ahn GH, Moon JS, Shin SY, In WK, Han NS, Seo JH (2015) A competitive quantitative polymerase chain reaction method for characterizing the population dynamics during kimchi fermentation. J Ind Microbiol Biotechnol, 42, 49-55

28. Provesi JG, Dias CO, Amante ER (2011) Changes in carotenoids during processing and storage of pumpkin puree. Food Chem, 128, 195-202

29. Lee JH, Lee MK (2013) Quality characteristics of jelly incorporated with sweet pumpkin powder. J Korean Soc Food Sci Nutr, 42, 139-142

30. Qian C, Decker EA, Xiao H, McClements DJ (2012) Physical and chemical stability of $\beta$-carotene-enriched nanoemulsions: Influence of $\mathrm{pH}$, ionic strength, temperature, and emulsifier type. Food Chem, 132, 1221-1229

31. Song YC (2014) Optimized production of dextran, mannitol and GABA by co-fermentation using lactic acid bacteria isolated from kimchi. MS Thesis, Keimyung
University, Korea, p 18-25

32. Tingirikari JMR, Kothari D, Goyal A (2014) Superior prebiotic and physicochemical properties of novel dextran from Weissella cibaria JAG8 for potential food applications. Food Funct, 5, 2324-2330

33. Amrane A, Prigent Y (1998) Influence of yeast extract concentration on batch cultures of Lactobacillus helveticus: growth and production coupling. World $\mathbf{J}$ Microbiol Biotechnol, 14, 529-534

34. Yoo SK, Kim DM, Day DF (2001) Co-production of dextran and mannitol by Leuconostoc mesenteroides. J Microbiol Biotechnol, 11, 880-883

35. Ryu BH, Kim DH, Yun JW (1996) Characteristics of mannitol production by Leuconostoc sp. KY-002. Korean J Biotechnol Bioeng, 11, 636-641

36. Jeanes A, Wilham CA, Miers JC (1948) Preparation and characterization of dextran from Leuconostoc mesenteroides. J Biol Chem, 176, 603-615 